\title{
AMAR UM AUTOR: OS MARXISTAS NAS UNIVERSIDADES BRASILEIRAS E OS "INTÉRPRETES DO BRASIL"1
}

To love an author: Marxists in Brazilian universities and the "interpreters of Brazil"

Amar a un autor: los marxistas en las universidades brasileñas y los "intérpretes de Brasil"

\section{LIDIANE SOARES RODRIGUES ${ }^{*}$}

\footnotetext{
${ }^{1} A$ pesquisa que embasa este artigo foi parcialmente financiada pelo Conselho Nacional de Desenvolvimento Científico e Tecnológico (CNPq) e pela Fundação de Amparo à Pesquisa do Estado de São Paulo (Fapesp). A coleta dos dados dependeu do envolvimento de numerosos marxistas, sem os quais esta pesquisa não teria sido possível. Às agências e a eles, nosso principal agradecimento.

' Universidade de São Paulo, (USP) São Paulo - SP, Brasil.

* Doutora em História Social pela Universidade de São Paulo (USP). Professora Adjunta do Dpto. de Ciências Sociais da UFSCar. (lidianesrgues@gmail.com), ORCID iD: https://orcid.org/ 0000-0003-2011-9888
}

Artigo recebido em 10 de março de 2019 e aceito para publicação em 26 de junho de 2019. 


\title{
RESUMO
}

Os marxistas que atuam em universidades brasileiras responderam a um questionário com 59 perguntas. Uma delas indagava: "Por quais autores/intérpretes do Brasil você tem mais interesse?" Com base nas respostas a essa pergunta, elaborou-se um ranking com suas predileções por determinados autores. Este artigo se propõe a identificar o princípio gerador da dupla escolha dessa lista: a dos marxistas por esses intérpretes e a desses intérpretes pelos marxistas. Para tanto, realiza uma caracterização sociológica dos respondidos e dos respondentes, assim como da representação que os segundos compartilham a respeito dos primeiros.

PALAVRAS-CHAVE: Sociologia Histórica das Ciências Sociais; Sociologia dos Intelectuais; História do Marxismo; Pensamento Social e Político Brasileiro; Universidades.

\begin{abstract}
Marxists working in Brazilian universities have answered a questionnaire with 59 questions. One of them asked: "Which authors/interpreters in Brazil are you most interested in?" Based on the answers to this question, a ranking was prepared with the predilections for certain authors. This article aims to identify the principle that rises from the double choice of this ranking: that of Marxists for certains "interpreters" and that of certains "interpreters" for Marxists. To this end, it carries out a sociological characterization of the respondents and the respondents, as well as the representation that the latter share about the former.
\end{abstract}

KEYWORDS: Historical sociology of social sciences; Sociology of intellectuals; History of marxism; Brazilian social and political thought; Universities.

\section{RESUMEN}

Los marxistas que trabajan en las universidades brasileñas respondieron a un cuestionario con 59 preguntas. Una de ellas preguntó: "¿En qué autores/intérpretes de Brasil te interesa más?" A partir de las respuestas a esta pregunta, algunos autores elaboraron una clasificación con sus predilecciones. Este artículo propone identificar el principio que genera la doble elección de esta lista: la de los marxistas por estos intérpretes y los intérpretes por los marxistas. Para ello, realiza una caracterización sociológica de los citados y los encuestados, así como la representación que estos últimos comparten sobre los primeros.Palabras clave: Sociología histórica de las ciencias sociales; Sociología de los intelectuales; Historia del marxismo; Pensamiento político y social brasileño; Universidades.

PALABRAS ClAVE: Teoría social; Sociologías indígenas; Teorías y sociologías del sur; Sociología africana; Yoruba. 
"Os clássicos são livros que, quanto mais pensamos conhecer por ouvir dizer, quando lidos de fato, mais se revelam novos, inesperados, inéditos." Italo Calvino

\section{OS MARXISTAS NAS UNIVERSIDADES BRASILEIRAS E OS "INTÉRPRETES DO BRASIL"2}

$\mathrm{N}$ a identificação de indivíduos com autores se encontra um dos princípios elementares da organização de disciplinas como filosofia e estudos literários. Como se caracterizam por práticas textuais eruditas - leitura vertical, explicação e comentário, estabelecimento de texto original, traduções etc. -, dirigidas a autores em torno dos quais seus praticantes vão se agregando, elas ensejam um espaço formado por kantianos, hegelianos, machadianos e outros. Em algumas configurações interdisciplinares, observa-se fenômeno idêntico - por exemplo, entre os pesquisadores da área de pensamento social e político brasileiro (Botelho e Schwarcz, 2011) e entre marxistas (Boito e Motta, 2012). No caso dos últimos, a centralidade da categoria "autor" é reforçada pelo fato de serem unificados por um (Karl Marx) e de se diferenciarem por meio de diversos, como Gramsci, Lukács, Althusser, entre outros (Rodrigues, 2011, 2016 b e 2019).

Embora a categoria "autor" já tenha sido discutida, tendo suas funções colocadas em suspenso, sendo questionada em sua ilusória estabilidade e recebendo o decreto de falecimento (Barthes, 2004; Foucault, 2001a, 2001b e 2008; Chartier, 2014b; Bourdieu, 2006), sua eficácia é tangível na vida social das ideias (Sapiro e Santoro, 2017). ${ }^{3}$ Assim, torna-se instigante investigar a produção social da predileção por autores subjacente à lógica de organização das configurações disciplinares e interdisciplinares que encontram neles seu princípio de unificação e segmentação. Eis o propósito do presente artigo. ${ }^{4}$

Alguns marxistas que atuam em universidades brasileiras responderam a um questionário com 59 perguntas, sendo uma delas "por quais autores/intérpretes do Brasil você tem mais interesse?". 5 Eis os nove nomes mais bem colocados: 


\begin{tabular}{|l|c|}
\hline \multicolumn{1}{|c|}{ AutORES/INTÉRPRETES } & $\%$ \\
\hline 1. Florestan Fernandes (f1) & $22,9 \%$ \\
\hline 2. Caio Prado Júnior (f1) & $20,9 \%$ \\
\hline 3. Ruy Mauro Marini (f2) & $3,5 \%$ \\
\hline 4. Carlos Nelson Coutinho & $3,3 \%$ \\
\hline 5. Celso Furtado & $3,2 \%$ \\
\hline 5. Ricardo Antunes & $3,2 \%$ \\
\hline 6. Antonio Candido & $2,7 \%$ \\
\hline 7. Sérgio Buarque de Holanda & $2,5 \%$ \\
\hline 8. Jacob Gorender & $2,2 \%$ \\
\hline 9. Francisco de Oliveira & $2,1 \%$ \\
\hline 9. José Paulo Netto & $2,1 \%$ \\
\hline
\end{tabular}

Este artigo se propõe a identificar o princípio gerador da dupla escolha desse ranking: a dos marxistas pelos "intérpretes" e a desses "intérpretes" pelos marxistas. Para tanto, realiza uma caracterização sociológica dos respondidos e dos respondentes, assim como da representação que os segundos compartilham a respeito dos primeiros.

Importa uma consideração prévia, de ordem teórica. Optou-se por adotar o enquadramento analítico da sociologia da cultura de Pierre Bourdieu e, simultaneamente, tomar distância do emprego de seu conceito de "campo", aliando-se ao refinamento hodierno de sua teoria, proposto por expoentes de sua herança intelectual. Essa atitude cautelosa considera as peculiaridades do mercado de bens simbólicos, indissociável dos sistemas de ensino nacionais em países de desenvolvimento capitalista periférico e tardio, com frágil poder geopolítico e econômico no espaço transnacional do intercâmbio econômico e cultural (Novais e Cardoso, 2009; Miceli, 2005 [1972], p. 125-156).

Foram inseridas, nas operações analíticas em ato, as reflexões subjacentes a essa conduta mais refletida e crítica ao uso indiscriminado da palavra "campo", que tem colaborado para a perda do poder explicativo desse conceito. Para tanto, adotou-se a sugestão de Gisèle Sapiro, segundo a qual, do conceito de campo, vale reter a ideia de "espaço de relações estruturado/ estruturante", orientando os agentes em sua luta uns contra os outros, uns com os outros, uns pelos outros - em detrimento de uma propriedade definidora deles: a autonomia (2013).

É essa propriedade que a prática cultural de países periféricos coloca permanentemente em questão, e sua operacionalização não pareceu profícua aos achados empíricos da enquete que embasa este artigo. Assim, supor que exista um "campo (autônomo) do marxismo" seria despropositado, por tudo que se exporá abaixo. Em contrapartida, a competição por 
trunfos investidos de valor próprio e sentido, no meio dos marxistas, dotados da capacidade de segmentar e hierarquizar, legitimamente, os próprios agentes do processo de segmentação e hierarquização, só pôde ser realçado pelo emprego das noções do polo restrito e ampliado do "mercado dos bens simbólicos" (Bourdieu, 2003) e da dominação simbólica com base na "crítica da razão escolástica" (Bourdieu, 2001).

Essas noções pontilham a obra de Bourdieu desde sua juventude, porém o presente trabalho mobiliza suas análises de maturidade, período em que sua atenção se dirige não apenas para os mecanismos determinantes do polo "dominante" da dominação simbólica (Bourdieu e Passeron, 1975), mas também para o papel ativo exercido pelos agentes dominados no trabalho de sua própria dominação (Bourdieu, 2002; 2015, p. 569-588). Essa perspectiva é basilar para a análise a seguir.

Por fim, a crítica à razão escolástica precisa ser sublinhada, já que também toma posição em relação ao estado das discussões. Este trabalho tenciona propor uma alternativa à oposição entre análises internalistas e externalistas que disputam o enquadramento da vida intelectual (Rodrigues, 2017a; Jackson e Praxedes, 2017). Para tanto, partiu-se da evidência de que a vida das ideias comporta dimensões não racionais e afetivas, de modo a eleger tal dimensão como objeto e empenhar-se em compreendê-la. Retoma-se esse ponto nas considerações finais.

\section{PRELIMINARES}

uscultar as motivações das respostas acima pressupõe delimitar o que a pergunta
coletou. É um ledo engano supor que ela mensure os autores mais lidos. 0 que ela apreende, ao contrário, é a crença no dever de lê-los - sentimento de obrigação que antecede a leitura, podendo ou não conduzir a ela. Por isso, a presente análise trata de uma dimensão não intelectual da vida intelectual. A despeito dos graus distintos de conhecimento, tanto os eleitores mais informados quanto os menos compartilham sentidos atribuídos aos autores, posto que estejam imersos no espaço autorreferenciado do marxismo. ${ }^{6}$

Os dois primeiros lugares se distinguem dos demais ( $f 2$ ) pela capacidade de integração no espaço, evidente na concentração das respostas (43,8\%), na distância porcentual entre $02^{\circ}$ e $03^{\circ}$ lugares e na dispersão que os sucede. ${ }^{7}$ Para este exame, consideramos os 277 indivíduos que elegeram os autores no topo do ranking - isto é, 43,8\% dos 632 respondentes selecionados, entre áreas de formação nas quais o termo "intérprete" assume sentido estável. ${ }^{8}$ 


\section{OS RESPONDIDOS: SOCIODICEIA PERSONIFICADA}

apreciação do ranking constatou que os autores induziram a leitura uns dos outros. Os
localizados da terceira à nona posições trabalharam pelo acréscimo de valor simbólico dos autores mais citados que do eles por meio de intervenções destinadas a isso (Netto, 1987; Coutinho, 2000; Antunes, 1998; Saviani, 1994; Oliveira, 2003; Konder, 1989; Candido, 1996; Gorender, 1987). Do mesmo modo que eles induziram leituras de Florestan Fernandes e Caio Prado Jr., o primeiro o fez em relação ao segundo (Fernandes, 1988, 1989, 1991ª e 1991b). ${ }^{9}$ Importam as circunstâncias de produção desses textos, que condicionaram a fatura e a recepção de seus conteúdos. ${ }^{10}$

Os artigos de Florestan Fernandes sobre Caio Prado Jr. e os dos autores da f2 que tratam de ambos foram produzidos a propósito de homenagens - aniversário de nascimento, falecimento ou cerimônia de consagração em vida. Os autores são liberados, pela natureza desses eventos, de certas convenções às quais os acadêmicos são submetidos regularmente. Neles, permite-se - e mesmo se requer - o afrouxamento do compromisso com referências bibliográficas e factuais precisas, daí a "citação de memória", tanto da obra quanto das lembranças do autor incensado. ${ }^{11} \mathrm{~A}$ autoridade simbólica de que os autores são investidos ao comentar uns aos outros torna impensadas e impensáveis as operações de seleção; enquadramento e articulação de sentido; classificação, apreciação e hierarquização daqueles(as) fragmentos biográficos/citações avulsas. ${ }^{12}$

Do mesmo modo que os paratextos secundários enquadram textos principais, tornando-os inteligíveis segundo os padrões do meio a que se destinam, os escorços biográficos - presentes em depoimentos, entrevistas, obituários, conferências - enquadram trajetórias. Os textos menores sobre os autores induzem leituras dos textos maiores dos autores, por meio da inculcação da crença no valor deles, do dever de lê-los, de categorias classificatórias (prévias) e, sobretudo, de um protocolo de indagações obrigatórias. ${ }^{13}$ As práticas de incensamento são dotadas de uma capacidade extraordinária de capilarizar certa representação dos autores e de suas obras. É precisamente o que se observa nos textos menores de Florestan Fernandes sobre Caio Prado Jr. 


\section{Caio Prado Jr., segundo Florestan Fernandes}

1) Ascese: "pensava que iria encontrar (na casa de Caio Prado Jr.) um ambiente luxuoso, requintado, de ostentação. Nada disso! [...] uma vida simples, moderada, espartana ornava o caráter [...] não recorria [...] ao prestígio de classe, pois já tinha renegado a classe. [...] 0 dever estava acima dos prazeres mundanos e do êxito passageiro. Ser forte e não ceder mesmo nas pequenas coisas não era uma virtude - era uma obrigação mínima!" (1989: 39)

2) Fidelidade e traição de classe: "Acho que a coisa mais difícil que fiz foi permanecer fiel à minha origem de classe" (1991b).

"Há pouca contradição no fato de eu ter ficado marxista. Minha história de vida encaminhava-me naturalmente nessa direção. Não obstante, porque me tornei assistente e mais tarde catedrático da Faculdade de Filosofia, fui visto como um ressentido. [...] Já com Caio houve uma quebra de lealdade, uma ruptura com a classe a que ele pertencia. [...] Ele poderia ter sido ministro do Estado, chefe de Estado, (mas) jogou tudo isso fora, [...] converteu-se em um traidor da classe. Só para comparativos: se não ficasse marxista, eu teria me acomodado às compensações da ascensão social, castrando-me como pessoa. [...] Caio não. Ele partiu do tope, fez o movimento inverso e no momento em que não havia crise moral no seio da classe dominante. Ao contrário, a classe dominante estava solidamente implantada no poder. [...] revolucionário convicto, que adere com armas [...] aos inimigos da grande burguesia (1989, p. 34).

"Nunca Ihe perguntei nada sobre sua ruptura total com sua classe" (1991a).

3) Como alguém se torna comunista e marxista? "Por um idealismo revolucionário, ele se tornou um ativista altamente qualificado da antielite [...]. Recebeu portanto, uma incompreensão rancorosa e uma exclusão ritual da alta sociedade, contra a qual se ergueu como um apóstata. Outros repetiram seu feito. No entanto, nem tal deserção nem tal ousadia continham o mesmo significado" (1989, p. 33). "Se a proposição do enigma está correta, a resposta procede de uma ruptura moral interior. (...) quem poderia ser, dentro de nosso cosmos cultural, mais marxista? (1991a). "Ele teve de vencer resistências psicológicas, barreiras sociais e conflitos humanos que Ihe devem ter sido muito dramáticos. [...] foi além e espatifou todas as concepções, os valores e suas próprias raízes, em uma transgressão [...] inquietações devem ter sido tormentosas (...) a transformação é, ao mesmo tempo, tão penetrante quão definitiva" (1989: 33)

4) 0 que é/deve ser, intelectualmente, um marxista? "A sua coragem [...] para admirá-lo ainda mais dentro e acima de sua produção como historiador, geógrafo, economista, cultor da lógica e da teoria da ciência, homem de ação e político representativo" (1991 a). 
“Estabelecia uma síntese, que na esfera acadêmica seria entendida como uma fusão entre história, economia, geografia e sociologia. [...] tinha em mente que [...] uma relação recíproca entre teoria e prática, conhecimento e transformação da realidade" (1988: 6)

5) Ser/dever ser de um marxista, os sacrifícios sem recompensas: "Imaginem o que aconteceu com Caio. A intrepidez [...] suportou equilibrada e serenamente as duas espécies de sanção (da classe com que rompeu, do Partido que não o reconheceu). [...] A sua coragem e o seu orgulho o preparavam para repelir as afrontas dos esbirros e a repressão policial. Fazia o seu aprendizado de intelectual revolucionário e descobria como eram tratados os de baixo e os que se viam banidos da legalidade por pertencerem ao PCB. Venceu, e as provas da vitória estão em sua carreira de militante, em sua fidelidade ao PCB e à causa de sua renovação. Essas provas valem tanto ou mais que seus méritos de historiador e suas credenciais de porte excepcional" (1989, p. 35). "O PCB [...] Representava uma promessa digna de fé, endossada por gente responsável, egressa do tope da pirâmide e do núcleo do sistema de poder. A revolta de Caio carregava consigo pois, uma carga explosiva e o expunha a todos os ódios, a todos os estigmas, a todas as perseguições ou difamações". (1989: 34-35)

\section{6) 0 que é/deve ser, institucionalmente, um marxista? Acadêmico destituído} de academia: "[...] a ditadura constrangeu a Faculdade de Filosofia, Ciências e Letras a perder a presença direta e ativa de uma mente fecunda" (1999, p. 11). "Por nós, ele teria ficado como professor [...] Sérgio (Buarque de Holanda) se aposentara contra a nossa vontade (e) só Caio poderia sucedê-lo e substituí-lo, à altura dos padrões mais exigentes da investigação histórica (1989, p. 28-29). "[...] Ele reaparece com todo o brilho, como expressão legítima da Faculdade de Filosofia, Ciências e Letras [...] e da qual tornou-se um mestre sem ter sido um professor de carreira" (1999, p. 11). "Caio representava o seu espírito e sustinha os seus avanços" (1989: 32).

7) No PCB - livre no espírito, obediente na prática: "(em Evolução política do Brasil, 1933) dá suas respostas aos membros da classe social dominante e ao PCB [...] para afirmar-se em toda a plenitude como um intelectual revolucionário livre, pronto avançar na conquista da revolução social e na emancipação dos excluídos, porém dotado de uma faculdade própria de submeter-se à disciplina e às orientações partidárias" (1991). "Caio, dentro de seu estilo objetivo, procedeu a uma análise de situações históricas distintas em termos comparativos e dela ousou tirar conclusões divergentes das que eram defendidas e impostas pelo PCB. [...] essa qualidade de enfrentar até o fim, até o fundo uma pergunta intelectual que exige extrema coragem e pode custar sacrifícios imprevisíveis, Caio possui em uma escala admirável e rara entre os intelectuais brasileiros" (1989: 38). 
Na representação acima, ressaltam-se as explicações da ação - em particular da adesão ao comunismo e ao marxismo (3) - motivada por ousadia, coragem, em escala admirável e rara - opondo-se implicitamente à covardia -, firmeza, intrepidez - opondo-se implicitamente ao titubeio, à frouxidão de convicções. 0 ponto de partida social avaliado pelo ponto de chegada político (2) sustenta a apreciação da fidelidade de Florestan Fernandes e da traição de Caio Prado Jr. às respectivas classes de origem e a depreciação da ascensão social (castração).

Há um trabalho de recompensa simbólica de escolhas antecipadamente representadas como pouco compensatórias (5), por meio da exaltação dos atributos necessários para suportar os sofrimentos da anomia anunciada: nem apoio em sua classe, nem inserção profissional, nem reconhecimento partidário (1, 3 e 6). Há um reforço de crenças compartilhadas, sobretudo no sentido da entrega desinteressada ao trabalho intelectual que desconhece fronteiras e visa ultrapassar limites (4 e 6).

Por meio desse investimento na vida do espírito, há a conversão da derrota em vitória (5), valorizada em sua dimensão sacrificial (7). Os elementos de uma sociodiceia coletiva se encontram cristalizados na representação dos autores no topo do ranking, conduzida por Florestan Fernandes, que conjuga a de Caio Prado Jr. à dele próprio. ${ }^{14} \mathrm{~A}$ resultante é um modelo gerador de condutas exemplares para um marxista. ${ }^{15}$ Tenha origens elevadas ou rebaixadas na estratificação social, ele é desencorajado das disputas temporais por prestígio e poder, seja no universo acadêmico, seja no espaço partidário, sendo compensado prévia e simbolicamente pelos esforços que orientará para o âmbito propriamente intelectual e científico, desvencilhado de limites (e pertencimentos) disciplinares. ${ }^{16}$

Há três dimensões da sociabilidade nas representações compensatórias: o pertencimento acadêmico e a expectativa de reconhecimento, com certeza de frustração; o pertencimento partidário, sem plena identificação; e as origens socioeconômicas. ${ }^{17}$

Os biógrafos/especialistas/marxistas em Florestan Fernandes são impelidos a tomar posição sobre as classificações conflitantes - o acadêmico e o político -, indagando-se a respeito da passagem de um ao outro, e dificilmente percebem os modos distintos de articulação desses polos ao longo da trajetória dele. Já os biógrafos/especialistas/marxistas em Caio Prado Jr. se veem impelidos a indagar como foi possível ser ele tão obediente no partido e tão criativo na vida intelectual, ${ }^{18}$ e dificilmente percebem quanto sua obediência e criatividade são devedoras de sua classe e da cultura comunista dos anos 1930-1960.

Esses sutis deslocamentos de perspectiva realçam as conexões de sentido construídas pelos fragmentos. Elas caracterizam uma metamorfose simbólica digna de nota, porém só evidenciada por uma reconstituição alternativa, orientada por outras indagações, como veremos na última seção. 
A seguir, apresentamos as bases materiais que dão suporte à crença na representação acima, isto é, a morfologia dos respondentes. Trata-se de caracterizar a relação entre as propriedades relevantes dos autores e as propriedades eficazes do espaço social dos marxistas, com o objetivo de compreender o princípio gerador das respostas.

\section{OS RESPONDENTES: ANATOMIA DE UMA PREDILEÇÃO AUTORAL}

osto que as dimensões mais problemáticas da experiência dos marxistas em questão
consistam no pertencimento acadêmico, no pertencimento partidário e em suas origens socioeconômicas, elas serão caracterizadas de maneira objetiva.

No que tange ao pertencimento acadêmico, todos os respondentes pertencem ao sistema universitário, pois sua participação na pesquisa se condicionava ao atendimento de três critérios: identificar-se como marxista, trabalhar como professor e/ou estudar em universidade pública ou privada e, se estudante, estar em nível de pós-graduação - mestrado, doutorado ou pós-doutorado. ${ }^{19} \mathrm{~A}$ bibliografia pertinente, entrelaçada a indícios colhidos em terreno, e algumas respostas do questionário permitem situá-los, aproximada e tendencialmente, em posições dominadas, do ponto de vista dos poderes temporais.

Os marxistas exercem efeitos no espaço. Eles são dotados de visibilidade promovida por pertencimentos múltiplos que alargam sua superfície de circulação - práticas disciplinares ou políticas, não necessariamente partidárias, como convocação à assinatura de manifestos e presença em manifestações, aparições nas mídias, em eventos editoriais etc. Essa atuação é mais tangível pelas reações que suscita entre os concorrentes. ${ }^{20}$ As respostas a duas perguntas são expressivas:

\begin{tabular}{|l|r|}
\hline $\begin{array}{c}\text { VOCÊ PERCEBE ALGUMA DISCRIMINAÇÃO NA UNIVERSIDADE/FACULDADE/ } \\
\text { DEPARTAMENTO EM QUE TRABALHA OU ESTUDA EM RELAÇÃO AO MARXISMO? }\end{array}$ & $\%$ \\
\hline Sim & 82,0 \\
\hline Não & 18,0 \\
\hline Total & 100,0 \\
\hline
\end{tabular}

\begin{tabular}{|l|r|}
\hline \multicolumn{1}{|c|}{$\begin{array}{c}\text { VoCÊ ENFRENTOU DIFICULDADES POR SE IDENTIFICAR } \\
\text { OU SER IDENTIFICADO COMO MARXISTA? }\end{array}$} & $\%$ \\
\hline Sim & 78,1 \\
\hline Não & 21,9 \\
\hline Total & 100,0 \\
\hline
\end{tabular}

Densos e dotados da capacidade de instar reações - o que é digno de nota num meio intelectual como o brasileiro, no qual o silenciamento consiste na estratégia de disputa por 
excelência contra os adversários que se pretendem eliminar -, os marxistas constituem um polo dominado, intelectual e institucionalmente, no conjunto das ciências sociais e das humanidades. Isso se evidencia tanto por sua ausência nos espaços de poder monopolizados pelas elites da política científica quanto pelo perfil acadêmico, sociológico e político delas, tendencialmente inverso ao deles.

A caracterização dos grupos geracionais situados nos organismos estatais e privados, de avaliação, fomento e financiamento do ensino e da pesquisa, é constituída de ex-militantes de extrema esquerda, alguns oriundos do comunismo, convertidos, em função de diversos condicionantes, ao campo científico e às convicções políticas liberais, opostas às dos marxistas (Rodrigues, 2017a; Rodrigues e Hey, 2017b; Keinert, 2011; Canêdo, 2009; Miceli, 1995). Por conseguinte, no que tange ao universo acadêmico, eles se encontram submetidos a regras que não formulam e não dispõem de capitais que os permitam disputar a formulação delas. Os efeitos práticos disso são tangíveis em algumas respostas - eles consideram importante 0 exercício de poder temporal, contudo raramente o alcançam.

\begin{tabular}{|l|r|}
\hline \multicolumn{1}{|c|}{ VOCÊ CONSIDERA IMPORTANTE ASSUMIR CARGOS? } & $\%$ \\
\hline Não & 9,9 \\
\hline Sim, é fudamental & 62,5 \\
\hline Sem resposta & 27,5 \\
\hline Total & 100,0 \\
\hline
\end{tabular}

\begin{tabular}{|l|r|}
\hline \multicolumn{1}{|c|}{ QuAIS CARGOS VOCÊ JÁ ASSUMIU? } & \multicolumn{1}{|c|}{$\%$} \\
\hline Pró-reitor ou cargos em pró-reitorias & 1,8 \\
\hline Diretor de faculdade ou instituto & 1,8 \\
\hline Chefe ou vice de departamento & 1,3 \\
\hline Coordenador ou vice de pós-graduação & 3,3 \\
\hline Coordenador ou vice de graduação & 0 \\
\hline Comissões para seleção para ingresso na pós-graduação & 10 \\
\hline Comissões de periódicos da faculdade ou departamento & 10,7 \\
\hline Comissões para distribuição e bolsas de pós-graduação e/ou iniciação científica & 11,9 \\
\hline Bancas de seleção de concurso docente & 25,6 \\
\hline Outros/Nenhum & 33,6 \\
\hline Total & 100,0 \\
\hline
\end{tabular}

A decalagem entre o reconhecimento da importância do exercício do poder temporal e a capacidade de exercê-lo é notável. Enquanto 62,5\% responderam sim à primeira pergunta acima, apenas $8,2 \%$ já ocuparam postos de poder mais elevados em suas instituições - pró-reitorias, diretorias, chefias e coordenação de programas de pós-graduação. ${ }^{21}$ 
Torna-se compreensível a eleição de figuras que, segundo Florestan Fernandes, padeceram de destituições análogas. Os dois autores se sacrificaram para a elaboração de uma obra de imenso valor espiritual, "importante, pioneira e clássica nas ciências sociais na América Latina" (Fernandes, 1989, p. 32); "depurado, como marxista e historiador, (...) propõe-se uma ambição ciclópica" (1991a) - não foram/não são compensados com postos seguros ("tornou-se mestre sem ter sido professor de carreira" (1999, p. 11); "o sonho abortou" (1989, p. 29); e, tampouco dotados de poder temporal, recursos sem os quais os méritos intelectuais jamais são convertidos em reconhecimento simbólico (Bourdieu, 1984, p. 138-ss). Situados no topo deste ranking, são incensados por um segmento do campo acadêmico em posições dominadas, analogamente destituídas de glória e repleta de sacrifícios. Eis um dos eixos da eleição.

No que tange à esfera político-partidária, os marxistas se comportam de modo análogo ao caracterizado em relação à acadêmica. São ativos e efetivos, o que é igualmente tangível pela capacidade de suas intervenções suscitarem reações diversas e, sobretudo, midiáticas (Rodrigues, 2018b), bem como reconhecem a relevância institucional partidária. No entanto, tendem a se situar fora do exercício efetivo da política ou a se localizar em posições dominadas à esquerda da esquerda, para empregar uma categoria nativa. Quanto ao pertencimento partidário, o questionário constatou as seguintes predileções e filiações.

\begin{tabular}{|c|c|c|c|c|c|c|c|}
\hline \multicolumn{8}{|c|}{ OS MARXISTAS E OS PARTIDOS POLÍTICOS } \\
\hline \multicolumn{4}{|c|}{$\begin{array}{l}\text { Base: } 277 \text { respondentes eleitores do topo (dentre } \\
\text { os } 632 \text {, pertencentes às disciplinas selecionadas) }\end{array}$} & \multicolumn{4}{|c|}{ Base: 988 respondentes } \\
\hline Preferência & $\%$ & Filiação & $\%$ & Preferência & $\%$ & Filiação & $\%$ \\
\hline Nenhum & 27,8 & Nenhum & 68,6 & Nenhum & 30,2 & Nenhum & 72,1 \\
\hline PSOL & 18,8 & PCB & 7,2 & PSOL & 20,9 & PT & 6,8 \\
\hline PT & 17,0 & PT & 6,9 & PT & 15,2 & PSOL & 6,4 \\
\hline PCB & 16,2 & PSOL & 5,8 & PCB & 13,7 & PCB & 4,5 \\
\hline PSTU & 11,6 & PSTU & 5,4 & PSTU & 8,2 & PC do B & 3,5 \\
\hline $\begin{array}{l}\text { Consulta } \\
\text { Popular }\end{array}$ & 2,5 & $P C$ do $B$ & 2,2 & $P C$ do $B$ & 4,7 & PSTU & 3,3 \\
\hline$P C$ do $B$ & 2,2 & $\begin{array}{l}\text { Consulta } \\
\text { Popular }\end{array}$ & 1,4 & $\begin{array}{l}\text { Consulta } \\
\text { Popular }\end{array}$ & 1,5 & $\begin{array}{l}\text { Consulta } \\
\text { Popular }\end{array}$ & 1,1 \\
\hline
\end{tabular}

Observação: as organizações partidárias com menos de um indivíduo foram eliminadas da tabela. Por economia expositiva, indicamos a similaridade da distribuição proporcional, entre a base dos 277 indivíduos em foco e os 988 respondentes, mas suprimimos a das demais, que apenas repetiriam a constatação de que as tendências gerais colhidas pela pesquisa se encontram reproduzidas. Efetivamente, há princípios de coesão que unificam o espaço, e o topo desse ranking pôde documentá-lo de modo compacto. 
Dos 277 respondentes 27,8\% afirmaram não ter preferência por partidos. Os que afirmam ter alguma preferência se concentram, de modo equilibrado, entre PSOL, PT, PCB e, em menor proporção, PSTU. Já no que diz respeito à filiação partidária, a proporção quase se inverte. Enquanto 68,6\% afirmam não ser filiados a partido algum, 27,5\% se concentram entre PCB, PT, PSOL, PSTU e PC do B - havendo ainda uma distribuição muito dispersiva do restante. Como a tabela indica, a proporção invertida, em termos de filiação/preferência, do conjunto dos 988 indivíduos, é reproduzida entre os 277. Tudo se passa como se a proporção de indivíduos filiados a partidos correspondesse ao dobro de indivíduos cuja predileção partidária não passa à prática política partidária efetiva.

A morfologia torna compreensível a eleição de figuras que, segundo Florestan Fernandes, tiveram uma atividade partidária sem grandes recompensas e ao custo de grandes sacrifícios, como ruptura total com sua classe, ódio, estigma, perseguição, difamação. A relação problemática dos respondentes com os partidos aos quais poderiam se filiar e aos quais se esperaria que devotassem alguma predileção é refratada na relação problemática dos autores respondidos com o sistema partidário. A visibilidade política dos marxistas contrasta com seu exíguo engajamento partidário, um achado contraintuitivo desta pesquisa.

As posições e as tomadas de posição dos marxistas, nos sistemas partidário e universitário, tornam inteligível a escolha dos dois autores no topo do ranking, caracterizados nos termos de Florestan Fernandes. A posição duplamente dominada predispõe à identificação com "heróis vencidos" em sentido duplo: acadêmico e partidário. Vencidos porque não obtiveram glórias equivalentes a seus méritos e heroicos porque incensados por pares em posições homólogas. Observa-se a natureza recíproca dessa eleição.

No que concerne à terceira dimensão problemática, a fim de caracterizar de modo enxuto o perfil socioeconômico dos respondentes e as assimetrias em operação nesse meio, enfatizando o capital cultural de origem, tomou-se a escolaridade materna dos respondentes como indicador expressivo. Em seguida, eles foram segmentados segundo posse/ destituição do diploma de pós-graduação, na linhagem materna; e posse/destituição de um diploma de graduação universitária, ${ }^{22}$ chegando-se a uma divisão em três frações, distribuídas da seguinte maneira: 


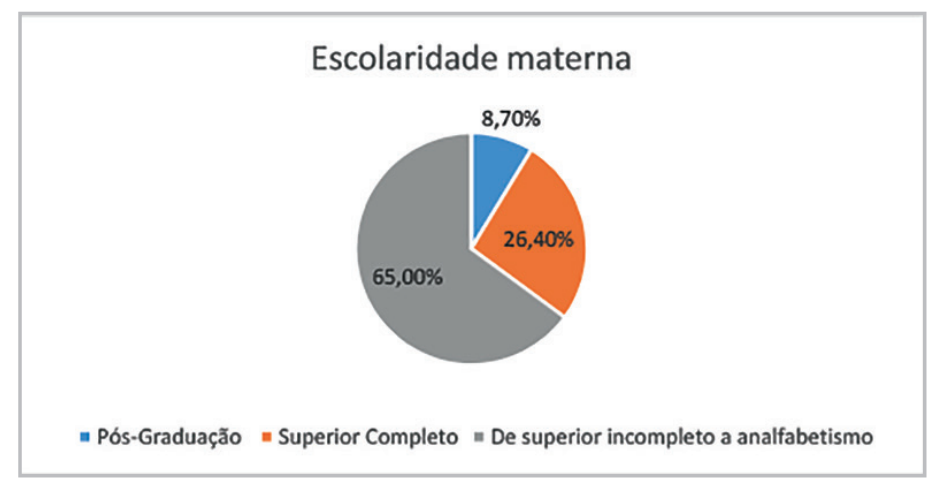

Trata-se de uma estrutura piramidal. No topo, apenas 8,7\% dos indivíduos apresentam um percurso escolar idêntico ao da mãe. No meio, encontra-se uma camada de $26,4 \%$ que ultrapassou a etapa mais longeva de escolaridade materna. Na base, uma imensa maioria, 65\%, representa a primeira geração de universitários de sua família materna. No espaço constituído pelos respondentes, essa parcela é 7,47 vezes mais densa do que o topo e 2,46 vezes mais densa do que a camada média.

Os polos extremos dessa estratificação, em detrimento das camadas e dos valores médios, comandam a dinâmica das trocas simbólicas, como se à heterogeneidade das origens culturais observada nas trajetórias dos dois autores favoritos dos marxistas correspondesse a das frações mais determinantes do ethos do espaço - que, juntas, conformam 73,7\%. Nas representações simbólicas mais recorrentes do grupo, os extremos - ousadia, firmeza, intrepidez, coragem - correspondem a um princípio de apreciação atitudinal e de depreciação da satisfação, típica das camadas médias, com a ascensão social (castração).

A possessão/despossessão observada acima é tributária parcial da morfologia mais ampla das universidades brasileiras e do sistema de pós-graduação vigente no país. ${ }^{23}$ Interessa a esta análise, contudo, que as assimetrias engendrem operações específicas de eufemização simbólica de um atrito potencial entre mais e menos investidos/destituídos de capital cultural - por exemplo, a depreciação da acomodação à ascensão socioeconômica, acima destacada, como fiadora da integridade de princípios morais e ideológicos.

A ascensão socioeconômica se formou numa base sobre a qual se ergueram os argumentos de justificativa para a expansão recente do ensino superior no plano dos investimentos públicos e dos estímulos para os indivíduos se dedicarem aos estudos (Costa, 2012). Há uma particularidade nesse meio, espécie de "cultura do contra", avessa a valores médios, condutas medianas, classes médias e conjunto de conotações que ela implica, sendo mais digno, seja a 
decadência do topo, seja a fidelidade às bases da pirâmide - exercida por indivíduos originários de uma ou de outra (Candido, 1978).

A seguir, tenciona-se evidenciar, por meio de uma reconstituição alternativa, orientada por outras indagações, a metamorfose da determinação em liberdade, operada na representação que Florestan Fernandes faz de Caio Prado Jr. Assim, certa modalidade de interesse desinteressado ficará patente.

\section{O FEITICEIRO E SUA MAGIA: A ALQUIMIA DAS TROCAS SIMBÓLICAS ENTRE MARXISTAS}

fim de provocar algum estranhamento nas leituras marxistas desses autores, propo-
mos um excurso biográfico comparativo das trajetórias de Florestan Fernandes e de Caio Prado Jr., ${ }^{24}$ adotando como eixos: o espaço social da cidade de São Paulo, entre o nascimento do mais velho e o falecimento de ambos (1907-1995); seus trunfos e handicaps; 0 leque limitado de escolhas face ao fechamento das oportunidades político-partidárias para as elites dirigentes em descenso - inércia da trajetória familiar herdada por Caio Prado Jr. -; 0 leque limitado de escolhas abertas face à abertura do dinamismo acanhado da modernização para as camadas remediadas - percurso de ascensão econômica, sem plena integração social, de Florestan Fernandes.

Em perspectiva objetivante, daí resultam duas carreiras simetricamente invertidas no que tange a seus pontos de partida e à orientação possível da ação, determinadas pelas condições em que foram obrigados a escolher/renunciar.

No período da vida intelectual produtiva dos dois, São Paulo era o epicentro da modernização econômica do país, e a produção cultural e científica da cidade foi impactada pela mobilidade social e pela imigração ligadas a esse processo histórico (Arruda, 2001; Pontes, 1998).

O autor que ocupa o primeiro lugar, Florestan Fernandes, tem origens modestas: é filho de uma imigrante portuguesa, empregada doméstica, e nem sequer conheceu seu pai. Seu percurso ascensional foi inteiramente dependente da oportunidade aberta pela criação da Universidade de São Paulo (USP), em 1934. 0 trabalho de construção institucional de uma nova ciência, a sociologia, significou para ele a superação de sua penúria, conferindo-lhe identidade e grupo de referência (Arruda, 1995; Pontes, 1998; Gemignani, 2002). Por isso, abriu mão das ambições de participação política que tanto marcam os intelectuais brasileiros - paulistas, em particular (Limongi, 1987). 
Ao se formar em ciências sociais, a dúvida a respeito do destino mais seguro o levou a transitar aqui e acolá, entre a entrega de produtos farmacêuticos e os trotskistas, tentando chamar a atenção do grupo Clima, que não the notou, até ter alguma segurança de que a Faculdade de Filosofia, Ciências Sociais e Letras (FFCL) da USP o abrigaria e o remuneraria. Seu engajamento efetivo na política - o trotskismo nos anos 1940 e o PT nos anos 1980 - ocorreu na fase de indeterminação no início do percurso e na de afrouxamento dos compromissos no final dele.

Seus temas e o modo de elaboração de suas ideias foram determinados pela competição com os pares em regime acadêmico, cujos exemplos cabais são uma leitura de Marx subordinada ao dever de construção institucional da sociologia (Rodrigues, 2016a); os estudos sobre A integração do negro na sociedade de classes (Fernandes, 2008 [1964]; 1976), concebidos contra a tese da democracia racial (Maio, 1999); e o "arremate de uma reflexão" (Arruda, 1996), isto, é A revolução burguesa no Brasil, escrito em resposta às teses gestadas por seu próprio núcleo na FFCL-USP (Rodrigues, 2011: 200-205; Martins, 2006: 157).

A colaboração com os interlocutores políticos decorre desse percurso e dessas teses, porém não os orienta. A evidência de que fosse chamado de "professor", quando eleito deputado constituinte pelo PT, é singela e expressiva a esse respeito (Rodrigues, 2010, 2017 a).

Sistematicamente, o inverso é observado no caso de Caio Prado Jr., que viveu livre das constrições econômicas que limitaram as escolhas do primeiro colocado, dispondo de capital social, material e cultural indisponíveis a Florestan Fernandes. Na qualidade de filho de uma família abastada e decadente de fazendeiros do café, seus investimentos no campo cultural - sobretudo no ramo editorial, em expansão - foram uma resposta ao risco de descenso econômico que atingiu esse estrato privilegiado das elites dirigentes paulistas.

Ele recebeu uma educação condizente com a dos homens de seu grupo e se preparou desde cedo para o exercício da vida política partidária: estudou com professores particulares; adolescente, viveu um ano na Inglaterra; formou-se em direito pela tradicional Escola do Largo São Francisco, celeiro dos destinados ao exercício da política (Venancio, 1977; Adorno, 1988). Nas décadas de recomposição das elites dirigentes, entre 1920-1945, os canais geracionais sucessórios entraram em crise e seu destino foi, como o de tantos outros, bloqueado (Rodrigues, 1996; Miceli, 2000, 2001). ${ }^{25}$ Não por acaso, portanto, como tantos jovens bem-educados, acabou por engrossar as fileiras do PCB, ao qual aderiu em 1932, aos 25 anos, após breve passagem pelo PD, segmentação interna da elite anteriormente agrupada no PRP.

No PCB, manteve-se numa posição de obediência política ao comitê central, em particular a Luiz Carlos Prestes, combinando-a com uma insubordinação imaginária e conformada. 
Sempre em desacordo com as teses oficiais do partido, editava os próprios livros e os de amigos, críticos ao partido. ${ }^{26}$ Seus temas preferenciais foram os do PCB, e é na oposição aos pares do partido que foi elaborando suas tomadas de posição. Essa orientação é evidente na fatura de Evolução política do Brasil, escrito já em controvérsia com os comunistas, por ocasião de sua adesão, porém também, por motivos opostos, em seu livro mais rente ao regramento da fatura acadêmica, como se configurava na seção de história e geografia da FFCL-USP (Rodrigues, 2013).

Formação do Brasil contemporâneo é redigido numa fase de recuo estratégico da vida política, em que o PCB e o próprio Caio Prado Jr. são perseguidos e estão em semiclandestinidade. Outro exemplo confirma a lógica da ação intelectual orientada para e pela esfera política. Tendo chegado enfim à prática para a qual foi educado - exercício efetivo da política, quando eleito deputado estadual -, abandonou a redação dos diários políticos, assim como o projeto de continuar Formação, em favor da dedicação absoluta a estudos que embasavam seus projetos de lei (Rodrigues, 2018c). Em suma, seus livros mais afinados com a fatura acadêmica são concebidos em momentos nos quais era prudente se afastar da esfera política, ao contrário de Florestan Fernandes, que, uma vez na esfera política, abdicava da fatura acadêmica, principal orientação das obras.

Enquanto o primeiro colocado é filho de uma imigrante e apresenta um trajeto de ascensão social e conduta intelectual orientada pelo incipiente campo científico, o segundo é um enraizado de família tradicional, apresenta um trajeto de descenso social e se orienta intelectualmente pelo campo político. A militância partidária não é definidora das escolhas iniciais que conduzem o primeiro, da fase de indeterminação à de envelhecimento social, mas determinam as escolhas iniciáticas do segundo nesse mesmo percurso. Observe-se a movimentação no espaço político e intelectual, do ângulo de gargalos e oportunidades, e a representação dos autores se modifica inteiramente. Eles se transformam de "intelectuais livres" em "agentes determinados", observada também na terceira dimensão problemática: as origens.

Com relação à fidelidade e à traição de classe, ambos se revelam mais fiéis sociologicamente ao destino coletivo de seus estratos do que deixa entrever os rituais de ruptura acima expostos. Nos momentos em que as trajetórias foram desafiadas por avalanches econômicas e políticas, o pertencimento de ambos às suas origens se evidenciou, a despeito da mobilidade. Os recursos de que se vale Caio Prado Jr., seja nos momentos de perseguição e clandestinidade do PCB, seja em suas prisões - ele viaja para a Europa, acionando o capital social familiar para defendê-lo -, são indicadores disso. Por outro lado, a posição distanciada da configuração intelectual dos cientistas sociais brasileiros nos anos 1970 e 1980, ocupada por 
Florestan Fernandes, consiste num indicador indefectível de que sua ascensão social não foi acompanhada de plena integração nesse espaço (Rodrigues, 2010).

Enquanto eles circulavam entre o Centro Brasileiro de Análise e Planejamento (Cebrap), o Instituto Universitário de Pesquisa do Rio de Janeiro (Iuperj) e os Estados Unidos, Florestan Fernandes foi para o Canadá, dando prosseguimento a um isolamento que já se configurava na crise institucional da FFCL-USP (Keinert, 2011; Miceli, 2001 e 1993; Rodrigues, 2018a). ${ }^{27}$

O sistema de oposições objetivas observado nas características invertidas - de origem e de orientação da ação - dos dois autores tem contrapartida na composição sociológica dos respondentes - a base massiva contrasta com a fração mínima de escolaridade prolongada equivalente à da mãe. Eis a base da metamorfose elaborada por Florestan Fernandes e talvez razão última da orquestração da sensibilidade e das crenças.

Sufocando os valores médios (ascensão, castração, ponderação, hesitação) e exaltando as atitudes extremas (ousadia, coragem, intrepidez) que enfrenta extremos (perseguições, difamação, estigma), Florestan Fernandes se dirige ao topo e à base dos respondentes, saciando suas demandas simbólicas. Ele é o agenciador mais importante da refração operada pelo espaço entre as propriedades sociais dos respondentes e dos respondidos, por meio de uma terceira operação: a metamorfose de um acadêmico em político (ele próprio) e de um comunista disciplinado num intelectual livre e acadêmico (Caio Prado Jr.), evidente no contraste entre a reconstituição acima e a que ele elaborou.

A constatação de oximoro de Pierre Bourdieu, segundo o qual "a ilusão da liberdade é determinante dos intelectuais" (2015, p. 458), torna-se precisa para o caso da representação de Caio Prado Jr. como um "intelectual revolucionário livre, pronto avançar na conquista da revolução social e na emancipação dos excluídos, porém dotado de uma faculdade própria de submeter-se à disciplina e às orientações partidárias" (Fernandes, 1991), isto é, sua ação de tudo independe, emanando da própria vontade.

A articulação dos três elementos, correspondentes às três dimensões problemáticas destacadas do sistema de representações exposto inicialmente, completa o sistema das crenças deste espaço: a crença na fidelidade do primeiro lugar a seu grupo de origem - em decalagem com a evidência objetiva de ter se desprendido dela, embora não tenha sido integrado aos grupos dirigentes -; na ruptura do segundo com o grupo de origem - em decalagem com a evidência objetiva de ter dependido inteiramente dos recursos dela, embora não tenha se mantido integrado a ela; no desinteresse de ambos pelos interesses materiais e pela consagração mundana. 
A imersão dos respondentes num meio movido pela interlocução entre agentes oriundos dos polos da estratificação social, denegando ambições e valores médios em favor de extremos, parece central para a compreensão disso. 0 interesse em fazer valer como valor 0 desinteresse é correlato à ruptura e à fidelidade de classe observada na morfologia do grupo. No topo, há alguma ruptura, pois os indivíduos estão "traindo" sua destinação social ao não se associarem a grupos dirigentes e dominantes nos partidos, nas universidades e na base, nesta por motivos inversos.

É preciso compensar, portanto, o desencaixe entre o ingresso num espaço no qual são estrangeiros - posto que o destino social familiar não previra seu ingresso na universidade e na pós-graduação -, mantendo-os fiéis às suas origens, na medida em que se situam em posições a elas equivalentes na lógica própria do espaço institucional (marxistas/dominados).

Essa experiência parece não ser exclusiva do meio marxista em análise. Segundo Christophe Charle, a tomada de posição socialista entre frações dos alunos da École Normale Supérieure no fim do século XIX consistia numa acomodação ao desajuste de que padeciam: a decalagem entre o ponto de origem (popular) e o de chegada (entre as elites). As práticas - de agremiação, de leituras coletivas, de militância - promoviam vínculos e solidariedade mútua entre indivíduos estrangeiros ao universo dos normaliens, carentes de integração nele (Charle, 1990, p. 99-100).

É possível aventar similitude entre essa experiência e a que vimos caracterizando. É evidente que, ao reunir os indivíduos com origens socioeconômicas discrepantes e heterogêneas, num espaço cujos contornos não são institucionais, em estrito senso - o marxismo não é uma disciplina, não emite diploma, não tem percurso regular, em etapas, para a formação - , 0 problema da coesão do conjunto se apresentaria. Talvez, por meio da alquimia das trocas simbólicas, as demandas de integração dos indivíduos e da configuração coletiva se satisfaçam. Afinal, é notável que o modus operandi das representações dos autores seja capaz de conferir sentido à ação e razão à desrazão, estabelecendo as crenças e reforçando o valor delas, estreitando vínculos entre aqueles que nelas se reconhecem.

\section{CONSIDERAÇÕES FINAIS}

s dimensões problemáticas da experiência dos marxistas se encontram equacionadas
na sociodiceia personificada pelos autores do topo do ranking, como representados por Florestan Fernandes. Sustentamos que tal representação exerça efeitos múltiplos, compreensíveis por dois fatores correlatos: a autoridade simbólica do comentador/indutor junto aos marxistas e a sensibilidade do meio ao conteúdo por ele veiculado. Assim, este artigo se 
empenhou em desvendar um dos impensados das disciplinas e das configurações aludidas, organizadas em torno de autores, como filosofia, estudos literários, PSPB e marxismo: a anatomia do interesse por um autor/intérprete, as condicionantes da eleição de um autor.

O princípio gerador das respostas exprime demandas simbólicas do meio satisfeitas por esses autores. Ambos personalizam a metamorfose da necessidade em virtude. A heterogeneidade do espaço, que recruta em polos tendentes aos extremos dos capitais econômicos e culturais, dando vazão a eles em detrimento das camadas médias e dos valores medianos, é compensada pela unificação simbólica em torno do princípio de inversão de classe e de independência institucional/material nos dois casos, considerando-os tanto separadamente quanto na dupla que compõem, pois os princípios que orientam a indução de Florestan Fernandes, seja de si mesmo, seja a biografia/obra de Caio Prado Jr., são os mesmos.

As origens e a posição problemática - dos respondidos e dos respondentes - nos sistemas partidário e universitário é esteio máximo de pureza do desinteresse e da liberdade. A necessidade feita virtude se torna alicerce da crença no desinteresse (dos bens materiais) interessado (nos bens espirituais), propriedade definidora, por excelência, dos espaços de produção simbólica (Bourdieu, 1996: 246-ss).

Dito de modo simples, tratamos da morfologia do amor que autores e obras nos despertam. Se o empenho for situado, porém, nas controvérsias em torno da vida intelectual, ele assume alguma complexidade, haja vista que o pressuposto da aposta analítica consiste no reconhecimento de experiências não intelectuais, dignas de análise própria, subjacentes à lógica da vida intelectual. Tentou-se, portanto, formular uma problemática que dispensasse a afanosa disputa entre internalistas e externalistas, já que se tratou também de experiências que antecedem o ingresso na vida do espírito e nessa polêmica, isto é, como (e por quê) as pessoas se interessam pelos autores. Importa uma reflexão a respeito disso, pois o empenho deste artigo é tributário de controvérsias cumulativas.

A problemática, o objeto e a abordagem enfatizaram dimensões fundamentais para o exame da dinâmica dos espaços de produção cultural em geral - produtos, produtores simbólicos e suas clientelas, distribuídos em polos de circulação restrita e ampliada (Bourdieu, 1996: 246316; Bourdieu, 2003b). Realçá-las permite, a título de sugestões finais, situar a interpelação desta pesquisa junto a algumas tendências da bibliografia sobre intelectuais e política no Brasil.

Sem colocar a qualidade dela em questão, apresentaram-se alternativas às polarizações autoexcludentes: internalistas x externalistas (Jackson e Praxedes, 2017), argumento político x argumento sociológico (Rodrigues, 2017 a); linhagens de ideias x construção social das 
linhagens (Brandão, 2007; Miceli, 2000). 0 tratamento da eficácia social da categoria "autor" (Sapiro e Santoro, 2017) e o cruzamento do ranking de predileções dos marxistas com observações de terreno em seus eventos se revelaram profícuos para isso.

A despeito de rivalizarem em torno dos quadros analíticos mais legítimos para a análise dos intelectuais brasileiros, os pesquisadores presos às referidas oposições estão em acordo impensado a respeito das escolhas obrigatórias que conformam seus estudos (Charle, 2006). Tanto internalistas/inclinados ao argumento político quanto externalistas/inclinados ao argumento sociológico convergem, em primeiro lugar, na escolha por casos de figura dominantes, que ocupam a hierarquia superior das leituras prestigiadas e são incensados.

Assim, Sérgio Buarque de Holanda e Gilberto Freyre são os protótipos no polo internalista, enquanto os artífices disciplinares, como Florestan Fernandes ou José Arthur Giannotti, se tornam o protótipo dos externalistas (Arruda, 1995; Rodrigues, 2011). Em segundo lugar, os dois polos tendem a eliminar o vetor público, como indutor das práticas de seus casos de figura, dando atenção preferencial para a interlocução (internalistas) e a competição (externalistas) intrapares do polo restrito. Os estudos sobre a atuação dos acadêmicos no âmbito editorial, contudo, têm mostrado sob duplo constrangimento, do perfil dos pares e da sua clientela simbólica - alunos e leitores (Rodrigues, 2018a; 2018d; 2018e).

Em terceiro lugar, os dois lados das oposições recíprocas se dividem quanto à eleição do processo de profissionalização disciplinar (internalistas) ou aos tempos longínquos de regime não disciplinar como objetos principais (externalistas), deixando a desejar alguma sistematização dos nexos entre os tempos pretéritos e o momento presente.

Devedor dos debates entre essas posições, o presente trabalho promoveu uma inversão destas três tendências: dedicou-se ao estudo de um segmento denso, situado em margens dominadas do campo acadêmico - em detrimento do privilégio de "casos de figura" dominantes -, situado no presente em curso; construiu o argumento investigando os nexos entre os conteúdos das mensagens, as posiç̧ões, as estratégias dos produtores delas e as demandas simbólicas da clientela simbólica disputada por eles - esforçando-nos para operacionalizar 0 programa inscrito na releitura bourdieusiana da sociologia da religião weberiana (Bourdieu, 2003); tratou de um segmento que não recebeu o enquadramento das teorias da diferenciação, talvez por se caracterizar justamente pela oposição à divisão do trabalho intelectual, ${ }^{28}$ isto é, postulou como válida a análise em termos de divisão social do trabalho de dominação também para agentes e grupos que não se definem como construtores de "campos disciplinares autônomos". ${ }^{29}$ 
Ponderadas as experiências históricas, a vida intelectual comporta avanços e recuos nos processos de institucionalização, disciplinarização, profissionalização e autonomização da atividade intelectual, e tanto a desprofissionalização quanto a heteronomização são estratégias à disposição de agentes interessados nelas (Charle, Jean-Pierre, 2016b; Hauchecorne, 2016; Sapiro, Heilbron, Boncourt e Schögler, 2017). Ainda que não tenha sido o principal alvo da análise, inclinações heterônomas foram colocadas em relevo, em oposição à visão de um crescente e irreversível processo de autonomização e profissionalização do trabalho acadêmico - no mais, insustentável, face à nova morfologia universitária e às demandas carreadas por ela (Rodrigues, 2018b).

\section{ANEXOS}

1) Ranking de autores, considerando os 988 respondentes, até a 12 a posição $(69,7 \%)$.

\begin{tabular}{|l|r|}
\hline RESPOSTAS & \multicolumn{1}{|l|}{$\%$} \\
\hline $1^{\circ}$ Florestan Fernandes & 214 \\
\hline $2^{\circ}$ Caio Prado Junior & 159 \\
\hline $3^{\circ}$ José Paulo Netto & 6,9 \\
\hline $4^{\circ}$ Carlos Nelson Coutinho & 5,3 \\
\hline $5^{\circ}$ Ricardo Antunes & 4 \\
\hline $6^{\circ}$ Demerval Saviani & 2,9 \\
\hline $7^{\circ}$ Ruy Mauro Marini & 2,7 \\
\hline $8^{\circ}$ Francisco de Oliveira & 2,5 \\
\hline $9^{\circ}$ Celso Furtado & 2,4 \\
\hline $10^{\circ}$ Leandro Konder & 2 \\
\hline $11^{\circ}$ Antonio Candido & 1,8 \\
\hline $12^{\circ}$ Sérgio Buarque de Holanda & 1,8 \\
\hline Total & $697 \%$ \\
\hline
\end{tabular}


2) Escolaridade dos pais dos 277 respondentes (dados desagregados).

\begin{tabular}{|c|c|c|c|c|}
\hline \multicolumn{5}{|c|}{ EsCOLARIDADE } \\
\hline & \multicolumn{2}{|l|}{ PAl } & \multicolumn{2}{|l|}{ MÃE } \\
\hline & $\begin{array}{l}\text { Base: } 277 \text { respondentes } \\
\text { do topo }(\%)\end{array}$ & $\begin{array}{l}\text { Base: } \\
988(\%)\end{array}$ & $\begin{array}{l}\text { Base: } 277 \text { respondentes } \\
\text { do topo }(\%)\end{array}$ & $\begin{array}{l}\text { Base: } \\
988(\%)\end{array}$ \\
\hline Analfabeto & 1,8 & 2,6 & 1,4 & 1,7 \\
\hline Fund. Incom. & 28,2 & 26 & 23,1 & 22,7 \\
\hline Fund. Compl. & 9 & 8,8 & 10,5 & 10,1 \\
\hline Médio Incom. & 3,2 & 5 & 4,7 & 5,0 \\
\hline Médio Comp. & 18,8 & 16,9 & 20,2 & 21,3 \\
\hline Superior Incom. & 3,6 & 5,5 & 4,7 & 5,6 \\
\hline Superior Comp. & 25,3 & 25,2 & 26,4 & 24 \\
\hline Pós-graduado & 9,4 & 9,3 & 8,7 & 9,2 \\
\hline Não sei & 0,7 & 1,9 & 0,4 & 0,5 \\
\hline
\end{tabular}

\section{NOTAS}

1 A coleta dos dados foi realizada em conjunto com Profa Dra Paula Marcelino. Agradeço por discutirem comigo este trabalho, em diferentes etapas da elaboração, a Frédéric Lebaron, Johan Heilbron, Laurent Jeanpierre, Horacio Tarcus, Sergio Miceli, Marcelo Ridenti, Maria Alice Rezende de Carvalho, Ana Maria Almeida, Ana Paula Hey, Edson Farias, Graziela Perosa, Bernardo Ricupero, Luiz Carlos Jackson, Armando Boito Jr. Também sou grata aos pareceristas anônimos de diversas publicações e das agências mencionadas, cuja exigência de rigor tem sido acompanhada de generosidade e estímulo. Por fim, agradeço aos desafios lançados pelos presentes nessas ocasiões, aos quais tento responder com este artigo. Como de praxe, declaro que assumo inteira responsabilidade pelas conexões de sentido apresentadas.

2 Trabalho financiado pelo CNPq e pela Fapesp. Ocultam-se informações para manter anonimato

30 leitor ligará esta discussão à ideia de "função autor", elaborada por Michel Foucault (2001a, 2001b, 2008), e esse é decerto o ponto de partida, por se tratar de uma das concepções mais comuns entre nós: a proposta de colocar em suspenso a crença na delimitação e na estabilidade das categorias "autor" e "obra". A retomada dessa discussão por Roger Chartier também orienta este trabalho (2014 a, 2014b, 1990, 2002; Chartier, Bourdieu, Darnton, 1985).

40 fenômeno se processa de tal modo que o espaço social - dos "especialistas em autores" - e o dos temas/ autores (simbólico) se tornam homólogos. 0 campo filosófico francês já foi estudado por meio desta abordagem (Soulié, 1995), em que se baseia este artigo.

5 Convém esclarecer que a pergunta era aberta e permitia até três respostas. 0 ranking acima e a análise a seguir consideram apenas a primeira, a mais propícia para apreender a estrutura do espaço (Bourdieu, 2003). Ao todo, obtivemos 988 respondentes, que compõem o banco da pesquisa. Em vez de segregarmos a exposição da coleta dos dados, optamos por apresentá-la conforme a necessidade dos argumentos. 
6 A análise se limita às práticas e aos artefatos produzidos para e pelos marxistas, daí empregarmos a noção de "espaço autorreferenciado".

7 Entre os 988 indivíduos, havia 128 nomes diferentes; entre os 632 selecionados para este exame, 97. Não é possivel discutir essa multiplicidade, mas vale uma observação, a fim de justificar a análise do topo do ranking: a dispersão a partir do terceiro lugar indica a diversidade dos "marxismos" e a divergência de parâmetros compartilhados de excelência num sistema universitário de centralização problemática. No topo, portanto, encontra-se a dimensão de unificação do espaço.

8 Antropologia, arquitetura, ciências sociais, direito, economia, filosofia, geografia, história, letras. A noção de "intérprete" não tem os mesmos significado e peso em todas as áreas, portanto a necessária seleção das que evidenciam mais proximidade na atribuição de sentido ao termo. Para chegarmos a isso, consideramos as disciplinas como espaços sociais e cognitivos (Heilbron; Bokobza, 2015; Renisio, 2015; Fabiani, 2006; Abbott, 2000) e nos embasamos nos estudos sobre a gênese social da "academização" da obra de Karl Marx (Almeida; Cavalieri, 2018; Rodrigues, 2011).

9 Ainda que a ordem sequencial do ranking não seja o objeto principal em análise, é válido assinalar que os estudos parciais já realizados indicam o papel de comando exercido por Florestan Fernandes no conjunto do escalonamento. Ocultam-se referências para preservar 0 anonimato.

10 As exceções são: Celso Furtado, Sérgio Buarque de Holanda, Caio Prado Jr. e Ruy Mauro Marini, que não participam do círculo de recíproco reconhecimento na qualidade de autores-comentadores dos outros autores do ranking. Avaliando a fração de autores coincidente com o cânone do PSPB - estabelecido pela observação dos autores mais presentes em suas atividades, além do site Biblioteca Virtual do Pensamento Brasileiro -, distinguimos aqueles que parecem ser específicos dos marxistas: os três primeiros. Infelizmente, a economia do artigo impede de explorar as afinidades entre o PSPB e o marxismo.o mesmo modo, no topoo do rankimente ao sentido atribuilos 988 indivtrajetorias dos autores e no mesmo modo, no topoo do rankio mesmo modo, no topoo do rankimente ao sentido atribuilos 988 indivtrajetorias dos autores e no mesmo modo, no topoo do rankilternativa a ela sentido neles que evidencia a : ue elas - ponto inteliglocuo com PSBolanda. Do mesmo modo, no topoo do ranki.

11 Há duas exceç̃̃es. Carlos Nelson Coutinho produziu o referido texto para o site Gramsci e o Brasil (Coutinho, 2000), e a coletânea sobre Celso Furtado é constituída de paratextos não orais, mas de escritos - prefácios, apresentações e introduções - concebidos por Francisco de Oliveira (2003). Apesar das diferenças, a função de "enquadramento" é similar.

12 Realizamos observações em eventos e jamais presenciamos alguém indagar a respeito da precisão sobre citações textuais. Isso não significa que a clientela/plateia não seja um fator ativo na orientação do palestrante/ depoente, e sim que, liberada das convenções acadêmicas para propor suas conexões, sua clientela/plateia as aceita ou rejeita segundo outros princípios, igualmente liberados delas. A "autoridade sobre os autores" pode se fundamentar em vários vínculos - familiares, pessoais, político-partidários etc. 0 título de um dos textos utilizados é indicativo da força simbólica da amizade como fiadora de autoridade: "A visão do amigo" (Fernandes, 1989).

13 A respeito dos aparatos e das hierarquias textuais, ver Genette, 2009; Mollier, 2009; Chartier, 2014.

14 Empregamos "sociodiceia" na acepção de Pierre Bourdieu (2003a): narrativas que sistematizam a história coletiva e conferem sentido às experiências constitutivas de uma configuração.

15 Mais preciso seria afirmar para um "marxista homem". A evidente virilização dos atributos, eivados de conotações bélicas e fálicas, corresponde à homogeneidade de gênero dos autores. Trata-se de um ponto que não se pode explorar devidamente neste artigo, porém tampouco deixar de assinalá-lo. 
16 A diferenciação dos dois tipos principais de poderes e de reconhecimento - o espiritual e o temporal, referindo-se, respectivamente, ao domínio dos conteúdos propriamente intelectuais e ao controle das condições materiais e institucionais que viabilizam as práticas (Bourdieu, 1984: 138-ss) - é fundamental no argumento e retomada adiante.

17 Argumentar em favor da correção indiscutível do que afirma Florestan Fernandes para explicar a vigência dessas representações implicaria supor que a crença nelas depende apenas da consistência das ideias, e não das disposições daqueles a que elas se destinam. Os atributos incensados seriam destituídos de sentido e 0 ranking seria outro, caso fossem outros os respondentes. Em contrapartida, os fragmentos mobilizados são verídicos; não se trata de invenção arbitrária.

18 A título de exemplares desse tipo de pertencimento aos protocolos estabelecidos pelo gerenciamento de Florestan Fernandes, consultar, para o caso de Caio Prado Jr.: D'incao, 1989; Martinez, 2008; Secco, 2008; Pericás, 2016; Ricupero, 2000; e, para Florestan Fernandes: D'incao, 1987; Martinez, 1998. Em perspectiva diversa: Rodrigues, 2018c, sobre Caio Prado Jr.; e Arruda, 1995; Gemignani, 2002, sobre Florestan Fernandes).

19 Os critérios se subordinaram aos propósitos iniciais da pesquisa: a) recusa de qualquer definição prévia ou normativa de marxismo e consequente interesse em todos que se identificam com ele (Tarcus, 2007, p. 29); b) constatação de que o marxismo atual depende de práticas eruditas e acadêmicas opostas às do campo político em que emergiu (Rodrigues, 2011; Gouarné, 2013; Tarcus, 2007; Boito; Motta, 2012; Hubmann, 2012; Schöttler; Grandjonc, 1993), havendo interdependência e concorrência entre os polos mais "academizados" (Elias, 1982) e os mais "partidários". A permeabilidade dos sistemas universitário e partidário foi apreendida pelo escrutínio de preferências e filiações partidárias, as quais se apresentam abaixo. Por fim, selecionar professores e alunos de pós-graduação se justifica em virtude dos compromissos e do peso que a identificação assume nessas posições, diferentemente do que significaria em fases mais indeterminadas da trajetória.

20 Não ignoramos a possível distorção das respostas. Para contornar o viés, nós as consideramos em face a outras experiências, confirmando a evidência de que são capazes de suscitar efeitos expressivos disso no espaço (Cf. episódio público: Boschetti, s/d; Carta aberta à Capes).

$21 \mathrm{~A}$ primeira pergunta foi respondida por docentes e discentes; a segunda, apenas por docentes. No banco de dados, eles se distribuem, respectivamente, em $43,3 \%$ e $56,7 \%$.

22 Opinamos por segmentar os indivíduos segundo os critérios de possessão/destituição materna de pós-graduação, pois: a) todos os respondentes alcançaram esse nível educacional - portanto, mede-se até onde foram além do ponto a que a mãe chegou); b) dada a raridade do título no polo materno, opinar por ele torna mais evidente a assimetria.

23 Como nosso esforço neste artigo se dirige à dinâmica interna do espaço, entendemos não haver prejuízo ao argumento acima, a impossibilidade de precisar a proporção de indivíduos de primeira geração familiar/ materna, no sistema de alunos e diplomados da pós-graduação. Pelo mesmo motivo, adotamos uma clivagem própria, em detrimento daquela mais usual na sociologia da educação - primeira geração de graduados, e não filhos de mães pós-graduadas).

24 Insistimos, sem o objetivo de corrigi-las, senão de realçar seus princípios de enquadramento.

25 Ressalte-se a distância interpretativa: "Ele partiu do tope, fez o movimento inverso e no momento em que não havia crise moral no seio da classe dominante. Ao contrário, a classe dominante estava solidamente implantada no poder" (Fernandes, 1989: 34).

26 Infelizmente, não dispomos de espaço para dar os exemplos disso, mas as biografias os relatam bastante, ainda que os alinhave sob a tutela dos princípios de Florestan Fernandes e não destaquem que sua posição 
no espaço social chancelava vínculos ideológicos com o PCB e de amizade com configurações liberais e antivarguistas, por exemplo.

27 Seria possível voltar aos sete itens acima e rearranjar seus sentidos com base nesse escorço. Por exemplo, a austeridade ascética de Caio Prado Jr., sendo factualmente verossímil, talvez corresponda às práticas econômicas de restrição orçamentária de camadas em descenso, premidas pelos deveres de manutenção de um estilo de vida que se tornou oneroso e que, ao mesmo tempo, não pode ser abandonado (Miceli, 2000: 22-63; Trigo, 2001).

280 mesmo problema foi encontrado por Eric Brun no estudo sociológico dos situacionistas, e uma alternativa analítica idêntica foi desenvolvida por ele (Brun, 2014).

29 Tal como é a tendência na sociologia brasileira do campo acadêmico, salvo exceções dignas de nota, seja por orientarem suas atenções aos cientistas sociais como frações dominadas no campo do poder e prestando serviços aos aparelhos de Estado (L'estoile; Neiburg; Sigaud, 2002; Hey; Rodrigues, 2017a; Hey, 2008), seja por abordarem novos flancos de escrutínio, notadamente o das assimetrias globais (Silva, 2017; Maia et. al., 2016; Bringel; Domingues, 2017; Rodrigues, 2017b, 2018a).

\section{REFERÊNCIAS BIBLIOGRÁFICAS}

ABBOTT, A. Chaos of disciplines. Chicago/Londres: Chicago Press, 2000.

ADORNO, S. Os aprendizes do poder: o bacharelismo liberal na política brasileira. Rio de Janeiro: Paz e Terra, 1988.

ANDERSON, P. Considerações sobre o marxismo ocidental. São Paulo: Boitempo, 2004.

ALMEIDA, I. C. S.; CAVALIERI, M. A. R. 0 marxismo nos departamentos de ciências econômicas no Brasil durante a ditadura militar. Economia e Sociedade, São Paulo, v. 27, n. 2, 2018.

ALMEIDA, W. M. Os herdeiros e os bolsistas do Prouni na cidade de São Paulo. Educação e Sociedade, São Paulo, v. 36, n. 130, 2015.

ANTUNES, R. Florestan Fernandes: um espírito sintonizado com as lutas sociais. In: MARTINEZ, P. H. (org.). Florestan ou o sentido das coisas. São Paulo: Boitempo, 1998.

ARRUDA, M. A. N. A sociologia no Brasil: Florestan Fernandes e a "escola paulista". In: MICELI, S. (org.). História das ciências sociais no Brasil, v. 2. São Paulo: Sumaré, 1995.

ARRUDA, M. A. N. Arremate de uma reflexão: a revolução burguesa no Brasil de Florestan Fernandes. Revista USP, São Paulo, n. 29, 1996, p. 56-65.

BARTHES, R. O rumor da língua. São Paulo: Martins Fontes, 2004.

BOITO Jr., A.; MOTTA, L. E. Karl Marx no Brasil, 2012. Disponível em: www.portalcfh.ufsc.br/files/2014/06/ Marx_no_Brasil.pdf. Acesso em: 30 maio 2016.

BOTELHO, A.; SCHWARCZ, L. Simpósio: cinco questões sobre o pensamento social brasileiro. Lua Nova, São Paulo, n. 82, 2011, p. 139-159.

BOSCHETTI, I. Entrevista, s/d. Disponível em: www.cressrj.org.br/site/noticias/capes-afirma-que-metodo-dialetico-materialista-nao-e-cientifico-entrevista-exclusiva-com-ivanete-boschetti/. Acesso em: 11 fev. 2019. 
BOURDIEU, P. Homo academicus. Paris: Minuit, 1984.

__. As regras da arte. Gênese e estrutura do campo literário. Lisboa: Presença, 1996.

. Meditações pascalianas. Rio de Janeiro: Bertrand Russel, 2001.

Gênese e estrutura do campo religioso. In. MICELI, S. (org. e trad.). A economia das trocas simbólicas.

5 ed. São Paulo: Perspectiva, 2003a.

0 mercado dos bens simbólicos. In. MICELI, S. (org. e trad.). A economia das trocas simbólicas. 5 ed. São Paulo: Perspectiva, 2003b.

BRANDÃO, G. M. Linhagens do pensamento político brasileiro. São Paulo: Hucitec, 2009.

CANDIDO, A. 0 tempo do contra. In. DANTAS, V. Textos de intervenção. São Paulo: Livraria Duas Cidades/ Editora 34, 2002.

Florestan Fernandes, marxista, 1996. Disponível em: http://marxismo21.org/florestan-fernandes/. Acesso em: 19 jun. 2016.

CARTA ABERTA À CAPES. Disponível em: www.cfess.org.br/arquivos/CartaAbertaCAPES-9-6-2014.pdf. Acesso em: 11 fev. 2019.

CHARLE, C. Naissance des "Intellectuels" (1880-1900). Paris: Minuit, 1990.

. L'habitus scolastique et ses effets: a propos des classifications littéraires et historiques. In. CLÉMENT, F. et. al. L'inconscient académique. Paris: Editions Seismo, 2006.

; JEAN-PIERRE, L. Révolutions visibles e invisibles. In: CHARLE, C.; JEAN-PIERRE, L. (orgs). La vie intellectuelle en France: de 1914 à nos jours. Paris: Éditions du Seuil, 2016b.

CHARTIER, R. Por uma sociologia histórica das práticas culturais. In: CHARTIER, R. A história cultural: entre práticas e representações. Lisboa/Rio de Janeiro: Difel/Bertrand Brasil, 1990.

A mão do autor e a mente do editor. São Paulo: Fundação Editora Unesp, 2014a.

. O que é um autor? Revisão de uma genealogia. São Carlos: Edufscar, 2014b.

. DARNTON, R.; BOURDIEU, P. Dialogue à propos de I'histoire culturelle. Actes de la recherche en sciences sociales, Paris, v. 59, set. 1985, p. 86-93.

COSTA, F. de S. O Prouni e seus egressos: uma articulação entre educação, trabalho e juventude. Tese (Doutorado em Educação) - Pontifícia Universidade Católica, São Paulo, 2012.

COUTINHO, C. N. Marxismo e imagem do Brasil em Florestan Fernandes, 2000. Disponível em: www.acessa. com/gramsci/?page=visualizar\&id=90. Acesso em: 19 jun. 2016.

D'INCAO, M. História e ideal: ensaios sobre Caio Prado Júnior. São Paulo: Brasiliense, 1989.

. (org.) O saber militante: ensaios sobre Florestan Fernandes. São Paulo: Paz e Terra, 1987.

ELIAS, N. Scientific establishments. In.: ELIAS, N.; MARTINS, E.; WHITLEY, R. (orgs.). Scientific Establishments and Hierarquies. Dordrecht: D. Rieder, 1982.

FABIANI, J-L. À quoi sert la notion de discipline?. In. BOUTIER, J.; PASSERON, J-C; REVEL, J. Qu'est-ce qu'une discipline? Paris: Éditions EHESS, 2006. 
FERNANDES, F. A revolução burguesa no Brasil. São Paulo: Zahar, 1975.

. Circuito fechado: quatro ensaios sobre o "poder institucional". São Paulo: Hucitec, 1976.

A pessoa e o político. Nova Escrita Ensaio, n. 8, 1981.

. A visão do amigo. In: FERNANDES, F. História e ideal. São Paulo: Unesp/Brasiliense, 1989.

. Obra de Caio Prado nasce da rebeldia moral. Folha de S. Paulo, 7 de setembro de 1991 .

. Memória: entrevista - Florestan Fernandes. Perseu Abramo, n. 13, 1991 b.

. Os enigmas do círculo vicioso. In: FERNANDES, F. História e desenvolvimento: a contribuição da historiografia para a teoria e prática do desenvolvimento brasileiro. São Paulo: Brasiliense, 1999.

A integração do negro na sociedade de classes. 5 ed. São Paulo: Globo, 2008.

FOUCAULT, M. O que é um autor. In: FOUCAULT, M. Estética: literatura e pintura, música e cinema. Rio de Janeiro: Forense Universitária, 2001 a.

Ditos e Escritos: Estética: literatura e pintura, música e cinema. Rio de Janeiro: Forense Universitária, 2001b, p. 264-298

A arqueologia do saber. 7 ed. Rio de Janeiro: Forense Universitária, 2008.

GENETTE, G. Paratextos editoriais. São Paulo: Ateliê Editorial, 2009.

GORENDER, J. A revolução burguesa e os comunistas. In: D'INCAO, M. (org.) O saber militante: Ensaios sobre Florestan Fernandes. Rio de Janeiro: Paz e Terra, 1987.

GOUARNÉ, I. L'introduction du marxisme en France: philosoviétisme et sciences humaines (1920-1939). Rennes: Presses Universitaires de Rennes, 2013.

HAUCHECORNE, M. Essor et disciplinarisation des sciences humaines. In: CHARLE, C.; JEANPIERRE, L. (orgs). La vie intellectuelle en France: de 1914 à nos jours. Paris: Éditions du Seuil, 2016.

HEILBRON, J; BOKOBZA, A. Transgresser les frontières en sciences humaines et sociales en France. Actes de la recherche en sciences sociales, n. 210, 2015.

HUBMANN, G. Da política à filologia: a Marx-Engels Gesamtausgabe. Crítica Marxista, n. 34, 2012, p. 33-49.

IUMATTI, P. Caio Prado Jr:: uma trajetória intelectual. São Paulo: Brasiliense, 2007.

JACKSON, L. C.; PRAXEDES, D. Histórias das ciências sociais brasileiras. In. MICELI, MARTINS (org.). Sociologia brasileira hoje. Cotia: Ateliê Editorial, 2017.

KONDER, L. A façanha de uma estreia. In: D'INCAO, M. História e ideal: ensaios sobre Caio Prado Júnior. São Paulo: Brasiliense, 1989.

LIMONGI, F. Marxismo, nacionalismo e cultura: Caio Prado Jr. e a Revista Brasiliense, 1987. Disponível em: www.anpocs.org.br/portal/publicacoes/rbcs_00_05/rbcs05_02.htm. Acesso em: 12 jun. 2016.

MAIO, M. C. O Projeto Unesco e a agenda das ciências sociais no Brasil dos anos 40 e 50. Revista Brasileira de Ciências Sociais, v. 14, n. 41, 1999.

MARTINEZ, P. H. (org.) Florestan ou o sentido das coisas. São Paulo: Boitempo, 1998. 
MARTINEZ, P. H. A dinâmica de um pensamento crítico: Caio Prado Jr. (1928-1935). São Paulo: Edusp, 2008. MARTINS, J. S. Entrevista. In: BASTOS, E. R. et. al. Conversas com sociólogos brasileiros. São Paulo: Editora $34,2006$.

MATONTI, F. Intellectuels communistes: Essai sur l'óbéissance politique. La Nouvelle Critique (1967-1980). Paris: La Découverte, 2005.

MICELI, S. A Fundação Ford no Brasil. São Paulo: Sumaré/Fapesp, 1993. Intelectuais e classe dirigente (1920-1945). In: MICELI, S. Intelectuais à brasileira. São Paulo: Companhia das Letras, 2000.

Condicionantes do desenvolvimento das ciências sociais. In: MICELI, S. (org.). História das ciências sociais no Brasil, v. 1. São Paulo: Sumaré, 2001.

A noite da madrinha. São Paulo: Companhia das Letras, 2005.

MOLLIER, J-Y. A história do livro e da edição: um observatório privilegiado do mundo mental dos homens do século XVIII ao século XX. Varia História, Belo Horizonte, v. 25, n. 42, 2009, p. 521-537.

NETTO, J. P. A recuperação marxista da categoria de revolução. In: D'INCAO, M. (org.) O saber militante: ensaios sobre Florestan Fernandes. Rio de Janeiro: Paz e Terra, 1987.

NOVAIS, F. A.; CARDOSO, J. M. Capitalismo tardio e sociabilidade moderna. São Paulo: Fundação Editora Unesp, 2009.

OLIVEIRA, F. A navegação venturosa: ensaios sobre Celso Furtado. São Paulo: Boitempo, 2003.

PERICÁS, L. B. Caio Prado Jr: uma biografia política. São Paulo: Boitempo, 2016.

PEROSA, G; COSTA, T. Uma democratização relativa? Um estudo sobre o caso da expansão da Unifesp. In: Educação e Sociedade, São Paulo, v. 36, n. 130, 2015.

PONTES, H. 1998. Destinos mistos: os críticos do grupo Clima em São Paulo (1940-1968). São Paulo: Companhia das letras.

PRADO Jr., C. Evolução política do Brasil: colônia e império. 21 ed. São Paulo: Editora Brasiliense, 1994. Formação do Brasil contemporâneo. Colônia. São Paulo: Companhia das Letras, 2011.

RENISIO, Y. L'origine sociale des disciplines. Actes de la recherche en sciences sociales, v. 5, n. 210, 2015.

RICUPERO, B. Caio Prado Jr e a nacionalização do marxismo. São Paulo: Editora 34, 2000.

RODRIGUES, L. M. O PCB: os dirigentes e a organização. In: FAUSTO, B. (org.) História geral da civilização brasileira: o Brasil republicano. 6 ed. Rio de Janeiro: Bertrand Brasil, 1996.

. Florestan Fernandes: interlúdio. São Paulo: Hucitec, 2010.

. A produção social do marxismo universitário em São Paulo: mestres, discípulos e "um seminário" em São Paulo (1958-1978). Tese (Doutorado) - Faculdade de Filosofia, Letras e Ciências Humanas, Universidade de São Paulo, 2011.

Marx em três tempos de Florestan. Dois Pontos, v. 13, n. 1, 2016 a. 
. Leitores e leituras universitários de Karl Marx (São Paulo, 1958-1964). Intelligere - Revista de História Intelectual, v. 2, n. 1, 2016 b.

- Rivalidades científicas e metropolitanas: São Paulo e Rio de Janeiro, sociologia e ciência política. Urbana - Urban Affairs and Public Policy, v. XVIII, 2017a, p. 71-95.

. Um departamento municipal no ultramar francês: o cosmopolitismo de José Arthur Giannotti. Campos, Curitiba, v. 18, n 1-2, 2017b, p. 61-88.

Centralidade de um cosmopolitismo periférico: a 'Coleção Grandes Cientistas Sociais no espaço das ciências sociais brasileiras (1978-1990). Sociedade e Estado, Brasília, v. 33, n. 3, set.-dez. 2018a, p. 675-708.

. Uma revolução conservadora dos intelectuais (Brasil/2002-2016). Política e Sociedade, Florianópolis, v. 17, n. 39,2018 b, p. $277-312$.

. Caio Prado Jr.: historiador sem história. Os historiadores - clássicos da historia do brasil, v. 4. Rio de Janeiro: PUC-RJ/Vozes, 2018c.

. Poder, sexo e letras no marxismo à brasileira. Forthcoming, Repocs, São Luís, 2019.

SAPIRO, G. Le champ est-il national?. Actes de la recherche en sciences sociales, n. 200, 2013.

. HEILBRON, J.; BONCOURT, T.; SCHÖGLER, R. European social sciences and humanities (SSH) in a global context preliminary findings from the Interco-ssh Project, 2017.

. SANTORO, M. On the social life of ideas and the persistence of the author in the social and the human sciences. Sociologica, Bolonha, n. 1, 2017, p. 1-13.

SAVIANI, D. Florestan Fernandes e a educação. In: Estudos Avançados, São Paulo, v. 10, n. 26, 1994, p. 71-87.

SCHÖTTLER, P.; GRANDJONC, J. Une troisième Mega? Entretien avec Jacques Grandjonc. Genèses, v. 11, ก. 1, 1993.

SOULIÉ, C. Anatomie du goût philosophique.Actes de la recherche en science sociales, Paris, v. 109, 1995.

SECCO, L. Caio Prado Jr:: o sentido da revolução. São Paulo: Boitempo, 2008.

TARCUS, H. Marx en la Argentina: sus primeros lectores obreros, intelectuales y científicos. Buenos Aires: Siglo XXI, 2007.

TRIGO, M. H. B. Os paulistas de quatrocentos anos: ser e parecer. São Paulo: Annablume, 2001.

VENANCIO FILHO, Alberto. Das arcadas ao bacharelismo. São Paulo: Perspectiva, 1977. 